\title{
IMPACT OF COVID-19 ON PRIVATE PLANT NURSERY BUSINESS: A CASE STUDY OF SYLHET DISTRICT, BANGLADESH
}

\author{
Kakon Chakma ${ }^{1}$ \\ $4^{\text {th }}$ year Student, Faculty of Agriculture, Sylhet Agricultural University, Sylhet, Bangladesh
}

Saidur Rahman ${ }^{2}$

$4^{\text {th }}$ year Student, Faculty of Agriculture, Sylhet Agricultural University, Sylhet, Bangladesh

Umama Begum Ruba ${ }^{3}$

$4^{\text {th }}$ year Student, Faculty of Agriculture, Sylhet Agricultural University, Sylhet, Bangladesh

Shurashi Rani Das ${ }^{4}$

$4^{\text {th }}$ year Student, Faculty of Agriculture, Sylhet Agricultural University, Sylhet, Bangladesh

Rahinoor Akter ${ }^{5}$

$4^{\text {th }}$ year Student, Faculty of Agriculture, Sylhet Agricultural University, Sylhet, Bangladesh

Article DOI: https://doi.org/10.36713/epra6076

\begin{abstract}
The Plant nursery industry is an integrated section of the afforestation program in Bangladesh. Around 18000 plant nurseries are playing a vital role in employment creation and income generation. But due to Covid-19 shutdown, this industry faced a lot of difficulties. Considering the importance, this research was performed in Sylhet district to trace out the pandemic impact on private plant nursery business. Randomly 31 nurseries were selected to fulfill the objective and data were collected using semi-structured questionnaires through direct interviews. In the questionnaire, 5 points Likert scale was used to collect responses of nursery traders. The study analyzed the socio-economic attributes of nursery traders. The conducted survey found out nursery input, transport, and selling tasks were affected most owing to the pandemic and it forced them to adopt several strategies to manage the loss. The study also revealed important suggestions and recommendations for the betterment of the nursery industry which are expected to help students, researchers, policymakers, and entrepreneurs.
\end{abstract}

KEYWORDS:Covid-19, Impact, Nursery, Case study, Sylhet, Bangladesh. 


\section{SJIF Impact Factor: 7.001| ISI I.F.Value:1.241| Journal DOI: 10.36713/epra2016 ISSN: 2455-7838(Online) EPRA International Journal of Research and Development (IJRD)}

Volume: 6 | Issue: 1 | January 2021

- Peer Reviewed Journal

\section{I.INTRODUCTION}

To sustain the balance of ecology it is required to have 25 percent of forest land in a country. But overpopulation, unplanned urbanization, industrialization have caused a serious ecological imbalance in Bangladesh. The forest area of Bangladesh has been recorded to cover $25 \%$ of the entire land in 1936 but at present, this has declined to $10.96 \%$ of the entire land ( $W B, 2016)$. In 1994, the target of Bangladesh's National Forest Policy was to ensure 20 percent of the nation's forests and trees cover. To increase afforestation, in the mid of the $19^{\text {th }}$ century, Forest Department (FD) first introduce plant nurseries in Bangladesh for producing forest trees but later they enlarged their nurseries to commercial fruit trees on Government level (Amin, 2016). Few private nurseries were flourished and exhibited in the twentieth century. And now this particular sector is the largest division (Amin, 2016). Nurseries have become an integral section of afforestation program. As a consequence, need for nurseries is constantly increasing and new nurseries are emerging. As the nursery business field is growing, educated entrepreneurs are joining this business and thus creating employment opportunities. At present around 18000 nurseries in Bangladesh at where 69000 families are associated partially or fully rely on the plant nurseries for their living (Amin, 2016). Around 0.2 million people are directly associated with nurseries and 0.15 million number of farmers are connected with commercial horticulture and floriculture business (ITR, 2015). Nurseries are playing a vital role to sustain cities and towns. It is increasing greeneries and also have great contribution to the local economy and national economy.

In December 2019, Covid-19 contagious virus detected in Wuhan, China. The virus devastated quickly throughout the world and World Health Organization(WHO) declared it a pandemic. As per Worldometer (January12,2021) almost 1.95 Million people died. 8 March 2020, Bangladesh observed the first coronavirus cases. After detection, the Bangladesh government declared a lockdown. The lockdown effect has broken the synchronization of demand and supply, the chain of supply along with relationship with producers and workers also messed up. Overall activity from production to selling was interrupted. The lockdown has affected the income of 500 families in Narayanganj district who were involved in flower production and marketing (Kumar, 2020). Covid-19 pandemic slowed down flower production and commercialization with TK 250 crores loss (Bhuyan, 2020). A supply chain expert predicted that present marketing condition may hamper obtaining growth of total income (Kumar, 2020).

In Bangladesh, few studies have been carried out to found out Covid-19 impact on agriculture and related sectors (Begum et al., 2020; Kumar, 2020; Sarwar et al., 2020). But no research has been found about Covid-19 impact on plant nurseries. There are few studies on nursery business in Bangladesh ( ISLAM, 2006; Haque et al., 2007; Amin, 2016; BARI, 2016 ). In there, only one study found which is related to plant nurseries in the Sylhet region (Ahmed et al., 2008). Therefore, considering the facts, it has become necessary to examine the present status of the nursery business in Sylhet district. This study had conducted by following the survey method in Sylhet district, Bangladesh. The specific purpose of the conducted study-

$>$ Analyze the socio-economic attributes of private plant nursery business owners.

$>$ Find out which nursery activities were affected most due to shut down.

$>$ Owner adaptation strategy to manage the pandemic impact.

$>$ Owner choice of suggestion overcoming the pandemic effect.

The findings will help the policymakers to understand better about the current condition of nursery business. It is expected that policymakers would contribute in formulating effective policies for expansion of this industry. Likewise, entrepreneurs will understand the situation of the nursery business and there are further possibilities for the researcher to do more research.

\section{II.METHODOLOGY \\ Study Area}

The survey-based research was performed in Sylhet district, north-eastern part of Bangladesh. The coordinates of Sylhet $24^{\circ} 30^{\prime} \mathrm{N}$ and $91^{\circ} 40 \mathrm{E}$.

\section{Sources of Data}

To collect primary data a survey was carried out from 28 $8^{\text {th }}$ October 2020 to $10^{\text {th }}$ December 2020. Secondary data has been obtained from the journal, research articles, websites, and newspapers.

\section{Sample size and sampling technique}

To select nursery a simple random sampling was used. Randomly 31 nurseries were selected to collect data at the studied area.

\section{Collection of Data}

Data were collected by authors themselves. All the survey information was collected during the daytime and all precautionary measures of COVID19 were maintained during data collection. Responses were collected by using semi-structured questionnaires through face-to-face interviews.5 points Likert scale (5=Strongly agree, 4=agree, $3=$ neutral, 2 =disagree, $1=$ strongly disagree) was used to fulfill objectives of this study.

\section{Analytical technique}

Collected data were tabulated and analyzed by descriptive statistics such as frequency, percentage, mean derived from 5 points Likert type scale. 


\section{EPRA International Journal of Research and Development (IJRD)}

Volume: 6 | Issue: 1 | January 2021

- Peer Reviewed Journal

\section{III.RESULTS AND DISCUSSION}

\section{Socio-economic Attributes}

The study found that (Table 1), In the study area 100 percent of plant nursery business owners were male. It indicates commercial nursery business is dominated through males. A study discovered a similar observation which was performed in the Dhaka district, Bangladesh(Amin, 2016). Bangladesh is the toughest place for female business owners because women continue to be restrained by deeply rooted socio-cultural alongside financial constraints(Bangladesh, 2020). Among the owners, 29 percent were young adults (age between 18-35) and 71 percent were middle-aged adults (age between 36-55). Above 55 age no owner was found. It indicates middle-aged entrepreneurs are more active in this business. The Majority of owners were educated. Around 48.39 percent obtained tertiary education,38.71 percent had secondary education and 12.9 percent had primary education. They agreed that education has vital role in decision making, adaptation ability and developing economically. It's a clear indication of educated young participation as educated populace are highly joining this business. At Sylhet, the study revealed that 54.84 percent of owners established their nurseries in their land and 45.16 percent developed their nurseries by taking land as lease. Although there are lots of fallow land in Sylhet district. Still, there are issues to use those land for the nursery business. 58.06 percent of owners developed their nurseries between 30-60 decimal of land where 29.03 percent and 12.90 percent of owners conducted their nurseries above 60 decimals and

Table 1. Socio-economic attributes of private plant nursery business owners at Sylhet, Bangladesh. $(\mathrm{n}=31)$

\begin{tabular}{|c|c|c|}
\hline Variable & & Percentage \\
\hline \multirow[t]{2}{*}{ Gender } & Male & 100 \\
\hline & Female & 0.00 \\
\hline \multirow[t]{3}{*}{ Age(years) } & Young age adult ( $18-35$ ) & 29 \\
\hline & Middle age adult ( $36-55$ ) & 71 \\
\hline & Old age adult $(55<)$ & 0.00 \\
\hline \multirow[t]{4}{*}{ Level of education } & No formal education & 0.00 \\
\hline & Primary education & 12.90 \\
\hline & Secondary education & 38.71 \\
\hline & Tertiary education & 48.39 \\
\hline \multirow[t]{3}{*}{ Size of nursery(Decimal) } & $<30$ & 12.90 \\
\hline & $30-60$ & 58.06 \\
\hline & $60<$ & 29.03 \\
\hline \multirow[t]{2}{*}{ Land ownership } & Self & 54.84 \\
\hline & Lease & 45.16 \\
\hline \multirow{4}{*}{$\begin{array}{l}\text { Business } \\
\text { (years) }\end{array}$} & $1-5$ & 3.23 \\
\hline & $6-10$ & 51.61 \\
\hline & $11-15$ & 32.26 \\
\hline & $15<$ & 12.90 \\
\hline \multirow[t]{2}{*}{ Training experience } & Yes & 6.45 \\
\hline & No & 93.55 \\
\hline \multirow[t]{2}{*}{ Participation in tree fair } & Yes & 58.06 \\
\hline & No & 41.94 \\
\hline \multirow[t]{2}{*}{ Sources of Capital } & Self & 90.32 \\
\hline & Bank & 9.68 \\
\hline
\end{tabular}




\begin{tabular}{lll}
\hline & NGO & 0.00 \\
& Others & 0.00 \\
\hline Annual income (Crore) & $>1$ & 35.48 \\
& $1-2$ & 32.26 \\
& $2<$ & 32.26 \\
\hline
\end{tabular}

below 30 decimals of land respectively. Experience is always vital factor that helps an entrepreneur to manage a business more smoothly and efficiently (Mamun et al., 2018). Around 51.61 percent of owners were experienced in doing business for 6-10 years. 32.26 percent had experience for 11-15 years and 12.90 percent had experience above 16 years and only 3.23 percent of respondents had experienced between 1-5 years. Training paves way of skill acquisition technique and knowledge but a greater part of the owners received no training (93.55 percent). Tree fair is always great way to add extra income alongside the marketing of nursery. 58.06 percent of owners attended in tree fair. This outcome revealed that owners did not take a loan from NonGovernment Organization(NGO). Though nursery owners are interested in taking loan from bank but only 9.68 percent of owners have taken a loan from bank. A large portion around 90.32 percent of owners established their business by self-capital. Income level determines the financial status of a business. Around 35.48 percent of owner annual income was below one crore taka, 32.26 percent have an annual income between one to two crore taka and 32.26 percent of owners have annual income above two crores taka.

\section{Nursery Owner perception on the impact of Covid-19 in the plant nursery}

It was found from the conducted study (Table 2), a significant proportion of nursery owners agreed with such statement of, "Problem was high in transportation of nursery material" (100\%), "Production cost has increased a lot" (100\%), "Selling of product has decreased a lot" (100\%), "No advisory services were gained from agricultural representative" (97\%), "Input material price has increased a lot" (94\%), "Product marketing problem has increased" (81\%), "Accessing in credit facilities were very difficult" (77\%), "Product price has decreased" (68\%), "availability of materials was limited" (55\%) “. Meanwhile, a substantial number of nursery owners disagreed with the statements of "difficulties were high in performing daily activities"
(77\%), "labor wage was increased a lot" (90\%), "monitoring problem was high"(97\%), "labor availability was limited" (100\%), "problem faced during new plant production" $(100 \%)$, "management problem was high" $(100 \%)$, "wide number of product was damaged" (100\%) and "storage problem was high" $(100 \%)$ ".It means Covid-19 has affected the nursery business and owners recognized which activity faced difficulties and interruption throughout the shutdown. All kind of transportation system, even people's movement were restricted in Sylhet (Coronavirus, 2020). Consequently, input material was limited and the price increased a lot which increased total production cost. But owing to restriction, buyers decreased alongside product prices also decreased. Agricultural representatives were also failed to provide information. Also, small farmers and businessmen could not be able to access Government loan facilities (Uttom, 2020). Opposed to, owners faced the least difficulties in performing daily activities, management activities. Owing to the availability of laborers, the monitoring of management activities was not harder. Moreover, no problem was faced in the storing of plants. The finding is congruent with a report which was conducted by BRAC at the farmer level in Bangladesh revealed that Covid-19 shutdown caused production problem, marketing problem, lack of decent prices, higher price of input, and limited operation of markets(BDT 565bn Loss in Farmers' Income in 45 Days, 2020). This study supports several studies of Bangladesh that were conducted finding out the impact level of the Covid-19 in agriculture (Bhuyan, 2020; Kumar, 2020; Mannan, 2020). However, one study reported that sales had risen while the lockdown eased but the corporate sale and NGO sales had dropped to $50 \%$ and $40 \%$ respectively 
Table 2.Nursery owner perception on the impact of covid-19 in the Plant nursery business.

\begin{tabular}{|c|c|c|c|}
\hline Impact & \%Agree & \%Disagree & \%Neutral \\
\hline Problem was high in transportation of nursery material & 100 & 0 & 0 \\
\hline Production cost has increased a lot & 100 & 0 & 0 \\
\hline Selling of product has decreased a lot & 100 & 0 & 0 \\
\hline $\begin{array}{l}\text { No advisory services were gained from agricultural } \\
\text { representative }\end{array}$ & 97 & 3 & 0 \\
\hline Input material price has increased a lot & 94 & 0 & 6 \\
\hline Product marketing problem has increased & 81 & 19 & 0 \\
\hline Accessing to credit facilities were very difficult & 77 & 23 & 0 \\
\hline Product price has decreased & 68 & 32 & 0 \\
\hline Material availability was limited & 55 & 42 & 3 \\
\hline Difficulty was high in performing daily activities & 16 & 77 & 6 \\
\hline Labor wage has increased a lot & 10 & 90 & 0 \\
\hline Monitoring Problem was high & 3 & 97 & 0 \\
\hline Labor availability was limited & 0 & 100 & 0 \\
\hline Problem faced during production of new plant & 0 & 100 & 0 \\
\hline Management problem was high & 0 & 100 & 0 \\
\hline Wide number of product has damaged & 0 & 100 & 0 \\
\hline Storage problem was high & 0 & 100 & 0 \\
\hline
\end{tabular}

\section{Adaptation strategies}

Beginning of the lockdown was most difficult time for business. To manage pandemic impact nursery owners intended to follow diverse types of strategies. The analysis found that (Table 3), a major portion of nursery traders $(35.48 \%)$ depended on savings. Low investment and high profits in the nursery business enable nursery owners to be reliant

Table 3. Nursery Owner's adaptation strategies to manage the pandemic impact. $(n=31)$

\begin{tabular}{lll}
\hline Strategy & Percentage \\
\hline No plan & 9.67 \\
Increased alternate income & \\
source & & 6.45 \\
$\begin{array}{l}\text { Depended on savings } \\
\text { Sold asset }\end{array}$ & 35.48 \\
$\begin{array}{l}\text { Started online sale } \\
\text { Reduced production of new } \\
\text { plant }\end{array}$ & \\
\hline
\end{tabular}

on savings. $29.03 \%$ owners started the online sale, it worked significantly. Online sales have increased by 70-80 percent in pandemic since the past time(Hasan, 2020). $12.90 \%$ owners sold their assets and $6.45 \%$ owners increased income source. $6.45 \%$ reduced new plant production due to decline of sales. $9.67 \%$ of the owners had no plan.

\section{Suggestion to overcome the pandemic loss}

This study found out (Table 4) the most necessary list of suggestion which includes, government should subsidize, special transport service should be commenced to carry nursery material, improvement of marketing channel, government should reduce taxes on import of nursery material, nursery modernization, virtual training program arrangement should be commenced, mobile based information service should be commenced, online platform should be undertaken for only selling nursery product and interest-free loan should be arranged". The greater part of the owners wanted government subsidies to stabilize this industry again. They demanded transport facilities for nursery material. Limited transport caused a miserable impact on marketing and some owners showed priorities on improved marketing channels. Market structure influenced overall nursery activities. Besides the pandemic impact, nursery owners believe that irrelevant practices of middle man, poor communication system, transportation of 


\section{EPRA International Journal of Research and Development (IJRD)}

Volume: 6 | Issue: 1 | January 2021

- Peer Reviewed Journal

Table 4. Important list of suggestions by nursery owners

\begin{tabular}{lll}
\hline Suggestions & Mean & Rank \\
\hline $\begin{array}{l}\text { Government should } \\
\text { Subsidize }\end{array}$ & 4.935 & 1 \\
$\begin{array}{l}\text { Special Transport service } \\
\text { should be commenced }\end{array}$ & 4.870 & 2 \\
$\begin{array}{l}\text { Marketing channel required } \\
\text { to be improved }\end{array}$ & 4.838 & 3 \\
$\begin{array}{l}\text { Govt. should reduce taxes on } \\
\text { import of nursery material }\end{array}$ & 3.677 & 4 \\
$\begin{array}{l}\text { Use of modern technology } \\
\text { should be increased }\end{array}$ & 3.612 & 5 \\
$\begin{array}{l}\text { Virtual training service } \\
\text { should be commenced }\end{array}$ & 3.548 & 6 \\
$\begin{array}{l}\text { Mobile-based information } \\
\text { service should }\end{array}$ & & \\
commenced be & 3.548 & 7 \\
& & \\
$\begin{array}{l}\text { Online platform should be } \\
\text { commenced only for selling } \\
\text { nursery product }\end{array}$ & 3.483 & 8 \\
$\begin{array}{l}\text { Interest free loan should be } \\
\text { arranged for nursery traders }\end{array}$ & 3.419 & 9 \\
\hline $\begin{array}{l}\text { (n=31) Cut-off score=3.0 (>3.0 } \\
\text { suggestion, }<3.0=\text { important }\end{array}$ & & \\
\end{tabular}

products without any storage facilities, unfair prices of products, products damaging are also salient features. Owners were engaged in the importation of nursery material. So, they wanted low tax because high tax increases input material price which led high product prices. In the present situation, it will create more difficulties. Social distance reduced the working efficiency of workers. Modern technology will assist to improve production and management activities. They recommended virtual training services, mobile-based information services so that they could communicate easily and they need not to present physically. They already started online selling but they want a trustable app, website only for selling nursery products will assist to grow business. Owners are not inspired enough due to high-interest rates, delay in loan approval, difficulties in understanding procedures, dissatisfactory client services, time- consuming procedures. They demanded an interest-free loan to decrease the pandemic induced impact.

\section{IV.CONCLUSION AND \\ RECOMMENDATIONS}

Plant nurseries act as a leading source of plant supply in Sylhet city. Nurseries have a great contribution to employment, environment and secure food security. This study found that mainly nursery input and marketing tasks have been largely affected due to covid-19. Nursery traders are facing losses that have force small traders to omit the business. Consequently, employment has become uncertain for many workers and Sylhet 's sustainability is now under threat. For the prosperity of this industry, the study is providing the following recommendations.

I. Government and NGOs need to provide easy financial assist for the nursery business. That will attract the young entrepreneur.

II. This industry has great export potentiality. So, research is required for uplifting this sector. Government and NGO should provide funds for this industry.

III. The Government should develop a suitable policy to use fallow, unfertile land for establishing nursery.

IV. This industry needs modernization. New technology will enhance the potency of activity. Modernization will enable this business to drive in the international market.

\section{CONFLICT OF INTEREST}

The authors declare that they have no competing interests.

\section{ACKNOWLEDGEMENT}

We are grateful to all the nursery owners who cordially helped us during data collection.

\section{REFERENCES}

1. Ahmed, R., Hasan, M. S., Halim, M. A., \& Alam, M. (2008). State of urban nurseries in Bangladesh: A case study from the north-eastern region. SmallScale Forestry, 7(3-4), 275-283.

2. Amin, M. (2016). Economic study of nursery business: Dhaka North City Corporation (DNCC) as a case [MS Thesis]. DEPT. OF AGROFORESTRY \& ENVIRONMENTAL SCIENCE.

3. Bangladesh: A tough place to be a woman entrepreneur. (2020, November 24). The Daily Star.

https://www.thedailystar.net/business/news/bangla desh-tough-place-be-woman-entrepreneur2000069

4. BARI, M. E. (2016). A COMPARATIVE STUDY ON PLANT SPECIES AND ECONOMICS OF NURSERY BUSINESS IN DHAKA CITY-A CASE STUDY [MS Thesis]. DEPT. OF AGROFORESTRY \& ENVIRONMENTAL SCIENCE. 


\section{EPRA International Journal of Research and Development (IJRD)}

5. BDT 565 bn loss in farmers' income in 45 days. (2020, June 4). BRAC. https://www.brac.net/latestnews/item/1283-bdt-565bn-loss-in-farmersincome-in-45-days

6. Begum, M., Farid, M. S., Alam, M. J., \& Barua, S. (2020). COVID-19 and Bangladesh: Socioeconomic analysis towards the future correspondence. Asian Journal of Agricultural Extension, Economics \& Sociology, 143-155.

7. Bhuyan, M. O. U. (2020, April 13). Flower industry faces coronavirus wrath. New Age|The Most Popular Outspoken English Daily in Bangladesh.

https://www.newagebd.net/article/104332/flowerindustry-faces-coronavirus-wrath

8. Coronavirus: Sylhet district locked down. (2020, April 11). The Daily Star. https://www.thedailystar.net/coronavirus-deadlynew-threat/news/coronavirus-sylhet-districtlocked-down-1891909

9. Flower business booming in Bangladesh. (2015, March 24). International Trade Centre. https://www.intracen.org/blog/Flower-businessbooming-in-Bangladesh/

10. Forest area (\% of land area)-Bangladesh $\mid$ Data. (2016). World Bank. https://data.worldbank.org/indicator/AG.LND.FR ST.ZS? locations $=B D$

11. Haldar, S. (2020, October 21). Nursery business grows as pandemic makes people think more of trees. The Business Standard. http://tbsnews.net/economy/nursery-businessgrows-pandemic-makes-people-think-more-trees147745

12. Haque, M. A., Miah, M. M., \& Rashid, M. A. (2007). An economic study of plant nursery business in Gazipur and Jessore Districts of
Bangladesh. Bangladesh Journal of Agricultural Research, 32(3), 375-385.

13. Hasan, A. (2020, August 23). The growth of ecommerce during the pandemic in Bangladesh. New Age | The Most Popular Outspoken English Daily in Bangladesh. https://www.newagebd.net/article/114200/thegrowth-of-e-commerce-during-the-pandemic-inbangladesh

14. ISLAM, M. S. (2006). QUALITY OF NURSERY OWNERS ON NURSERY BUSINESS (A CASE STUDY IN DHAKA DISTRICT) [MS Thesis]. DEPT. OF HORTICULTURE.

15. Kumar, D. (2020). COVID-19 Its instant impacts upon the agrarian economy of Bangladesh. 8, 193-199. https://doi.org/10.15413/jbem.2020.0127

16. Mamun, A., Rahman, A., \& Afrooz, N. (2018). A Socio-economic Analysis of Private Plant Nursery Business in Bangladesh. The Agriculturists, 16(02), 102-114.

17. Mannan, M. A. (2020, April 4). Coronavirus: Jashore farmers take the hit for falling vegetable prices. UNB. https://unb.com.bd/category/Special/coronavirusjashore-farmers-take-the-hit-for-falling-vegetableprices $/ 48681$

18. Sarwar, A. S. M., Razzak, K. S. B., Hossain, M. N., Nazmeen, F., Ferdous, J., Mahjuba, A., Rahman, S., Anik, M. E. I., Akter, S., \& Tabassum, T.-I. (2020). Impact of COVID-19 on Agro business in Bangladesh. SSB Global Journal of Medical Science, 1(01), 6-6.

19. Uttom, S. (2020, May 14). Covid-19 chokes farmers, traders in Bangladesh-UCA News. Ucanews.Com.

https://www.ucanews.com/news/covid-19-chokesfarmers-traders-in-bangladesh/88012 